\title{
Counteraction to Corruption Offences in Ukraine and the EU: Comparative Legal Aspect
}

\author{
Myroslav Yu. Durdynets ${ }^{1}$ \\ Raisa V. Perelyhina ${ }^{2}$ \\ Olga A. Klymenko 3 \\ Iryna M. Semeniuk ${ }^{4}$ \\ Lidiia M. Kostetska ${ }^{5 *}$ \\ ${ }^{1}$ National Academy of Internal Affairs, Kyiv, Ukraine \\ ${ }^{2}$ Kyiv University of Law of NAS of Ukraine, Kyiv, Ukraine \\ ${ }^{3}$ National Security and Defense Council of Ukraine, Kyiv, Ukraine \\ ${ }^{4}$ Kyiv University of Law of NAS of Ukraine, Kyiv, Ukraine \\ ${ }^{5}$ The National Academy for Public Administration \\ under the President of Ukraine, Kyiv, Ukraine \\ ${ }^{*}$ Corresponding Author
}

DOI: https://doi.org/10.36941/ajis-2020-010o

\begin{abstract}
The article focuses on counteraction to corruption offences in Ukraine and the EU. To this end, the authors conducted a consistent analysis of international legal acts in the field of combating corruption, in particular the United Nations Convention against Corruption of 10/31/2003; Council of Europe Criminal Convention for the Suppression of Corruption (ETS 173) No. ETS173 of 01/27/1999; Resolutions (97)24 of the Committee of Ministers of the Council of Europe on the Twenty Guiding Principles for the Fight against Corruption, etc. The study provides a systemic analysis of individual cases of experience in counteraction to corruption offences in EU countries. Experience of Great Britain, France, Germany, Belgium, Sweden, etc. is explored. The authors proved that all EU countries provide criminal liability for committing corruption offences. In different countries, criminal laws differ in the different levels of detailing of crime, as well as in the different content of the concept of corruption offence. It is proven that corruption must always be considered as criminal offence only. Today, such unambiguity is advisable in the fight against corruption in Ukraine, where the criminalization of a number of blatantly corrupt practices, such as unjust enrichment, lasts for a long period and is ambiguously effective. The article also concludes that the most effective approach of legal support for combating corruption is one that covers criminal prosecution, disclosure of information about public authorities and private entities, their income levels, their wealth, etc., as well as the interaction of law enforcement agencies with the fiscal authorities. On the example of EU countries, we showed that monitoring of financial information of public officials under the private and public laws with the proper level of analytical support for its processing provides the necessary basis for law enforcement agencies to initiate criminal proceedings for such crimes. Special attention is also paid to expanding the scope of administrative services provided by public officials as being covered by the attributes of corruption and lacking legislative support. This will significantly increase the level of transparency of the activity of public authorities, while reducing the level of corruption manifestations. An important conclusion of the article is that the effectiveness of criminal prosecution for committing corruption offences depends on the level of legal culture and the level of legal awareness of both the public and public servants.
\end{abstract}

Keywords: corruption offences, counteraction to corruption, criminal prosecution, international legal acts, civil society institutions 


\section{Introduction}

The development of democratic processes in Ukraine, the economic transformation and the improvement of the well-being of the population are the three spheres under the main influence of the Government and other public authorities. The implementation of long-term strategies for socioeconomic and socio-political development of Ukraine is the prerequisite that will eventually enable Ukraine to integrate into a single European community, but corruption hampers these processes. Corruption is a stable and objective phenomenon for many countries, but it has become rampant in Ukraine, threatening the existence of the statehood itself. The corruption network becomes, in fact, a parallel governing system in which economic issues are resolved not on the basis of laws, but on the basis of business interests of the most powerful oligarchs.

Corruption has become a systemic problem that plagues the most resilient state institutions, causing the government to cease fulfilling its obligations to the society, and perform only paid obligations to various groups of influence and elites. This situation rejects and prevents transparency of the state machinery, decision-making process, predictability of the investment climate and economic development. This, in turn, leads to inevitable economic and social losses. That is why corruption offences should and are prosecuted by the state as criminal offences. But this prosecution is not always in the public interest, and very often resembles fiction. For example, it was the case with the introduction in Ukraine, subsequent abolition and reintroduction of criminal liability for the socalled. In all EU countries, "unjust enrichment" is one of the most serious corruption offences, and the income monitoring system exists within the clear framework of democratic comprehensive protection of civil rights and freedoms.

Thus, in many respects, the EU experience is decisive and important for Ukraine. The current situation with organizational and legal support of criminal prosecution for committing corruption offences is a fundamental change. The objective of this article is to identify the priority systemic problems in the area of criminal prosecution for corruption offences in Ukraine, and to seek solutions thereto through the successful experience of EU countries. We understand that the criminal law aspect of the fight against corruption in Ukraine involves a rather limited range of aspects, public policy mechanisms and tools that can be used by state bodies, above all, the law enforcement system. On the other hand, in the EU countries, most of the measures aimed at combating crime are of political nature, with a broad involvement of civil society. Therefore, a number of objectives need to be fulfilled for this purpose, in particular:

- analyse the legislative framework of combating corruption in Ukraine;

- analyse the international legal support for counteraction to those offences;

- determine the peculiarities of application of the provisions of international legal acts in the EU countries, taking into account the peculiarities of their national legislation;

- determine the most effective mechanisms for counteraction to corruption offences in the EU countries, including at the stage of preventive measures, for implementation in the domestic legislation, and the appropriate system of instruments of criminal law prosecution for corruption offences.

\section{Materials and Methodology}

The theoretical background of this article is a series of international legal and European instruments that form the basic principles of legal regulation of corruption at the national level, namely:

- United Nations Convention against Corruption (Legislation of Ukraine, 2006b);

- Council of Europe Criminal Law Convention on Corruption (ETS 173) (Legislation of Ukraine, 2006a);

- Resolution (97) of the Committee of Ministers of the Council of Europe on the Twenty Guiding Principles for the Fight against Corruption (NKKSPK, 2014);

- The Charter of the Group of States against Corruption (GRECO) adopted by the Council of 
Europe on (Legislation of Ukraine, 1998);

- Council of Europe Civil Law Convention on Corruption (Legislation of Ukraine, 2005).

- Criminal codes of individual European countries and anti-corruption legislation of Ukraine were also investigated.

The issues of effectiveness and content of anti-corruption policies in the EU countries were examined through the works of such scholars as de Sousa (2010), Feldman (2020), Forgues-Puccio (2013), Kuris (2015), Shim and Eom (2008), and others. The nature of corruption manifestations, their significance and mechanisms of penetration into the system of public authorities were covered through the use of the works of Graycar and Prenzler (2013), Hamilton and Hammer (2018), Treisman (2007), and others.

An important direction of the article was to investigate the issue of legal provision of the consistent anti-corruption system, in particular the development of national anti-corruption strategies, involvement of civil society institutions, etc. Such issues were best explored in the works of Legvold (2009), Locatell et al. (2017), Moroff and Schmidt-Pfister (2010), Olken and Rohini (2012), Sampson (2010), Recanatini (2011), Seldadyo and de Haan (2011), Tabish and Jha (2012), etc.

Particular attention was paid to quite progressive views of Kaufmann and Pedro (2011) on the possibilities of legalizing some of the mechanisms and schemes of influence that remain corrupt today, but whose effectiveness is objective in addressing public administration issues.

Issues of legal support for combating corruption in Ukraine and the comparative legal aspect of its effectiveness compared to other countries were investigated by such Ukrainian scholars as Huzovatyi (2016), Ilienok (2013), Romaniuk (2009), Saprykina et al. (2011), Deineka et al. (2014), Shmyhelskiy (2014) and others.

In this study, we will try to answer a number of key questions:

- What are the most pressing or systemic problems of the anti-corruption system in Ukraine that need to be addressed first?

- What are the ways or mechanisms implemented to ensure counteraction to corruption, including prosecution for corruption in the EU countries, and how to apply this experience in Ukraine?

- What are the effectiveness and benefits of implementing appropriate measures in Ukraine's anti-corruption system?

The solution of these issues became possible by the use of the systemic method and the method of structural analysis. Comparative legal and formal legal methods were used to make comparative analysis of international legal acts and acts of national legislation in the field of combating corruption.

\section{Results}

Analysing the system of combating corruption in the EU and Ukraine, it is advisable to start with how the configuration and mechanisms of functioning of this system are enshrined at the legislative level. The following main international legal instruments should be noted:

United Nations Convention against Corruption (hereinafter referred to as UNCAC) (Legislation of Ukraine, 2006b). It seeks to promote and strengthen measures to prevent and combat corruption more effectively; encouraging, promoting and supporting international cooperation and technical assistance in preventing and combating corruption, in particular in the recovery of assets; promoting honesty, responsibility and proper management of public affairs and state property. Thus, the international community recognizes the importance of the fight against corruption as it emphasizes the need for international cooperation, that is, involving as many countries as possible in the process.

The Council of Europe Criminal Law Convention on Corruption adopted in 1998 is a commonly accepted instrument that introduces criminal penalties and prosecutions for corruption offences under the national law of EU Member States. The core value of this Convention is that it determines the general principles of cooperation in the said field, and determines the list of crimes covered by 
the generic term "corruption offences":

- bribe to public officials (Article 2);

- receiving bribes by public officials (Article 3);

- bribery of members of national representative bodies (Article 4);

- bribery of foreign public officials (Article 5);

- bribery of members of foreign representative bodies (Article 6);

- bribing in a private sector (Article 7);

- receiving bribes in a private sector (Article 8);

- bribery of officials of international organizations (Article 9);

- bribery of members of international parliamentary assemblies (Article 10);

- bribery of judges and officials of international courts (Article 11);

- undue influence (Article 12);

- corruption proceeds laundering (Article 13);

- financial crimes (Article 14) (Legislation of Ukraine, 2006a).

The 1998 Council of Europe Civil Law Convention on Corruption effectively obliges each EU Member State to include in its national legislation effective remedies for persons damaged by corrupt acts in order to enable such persons to defend their rights and interests, including the possibility of receiving compensation for the damage caused. In addition, it is for the first time in this Convention that EU law unifies the term "corruption". It means the direct or indirect demand, offering, giving or receipt of bribery or any other undue benefit, or ability to obtain it, that violates the proper performance of any obligation by the person receiving the bribe, undue benefit or the opportunity to have such benefit, or the behaviour of such a person (Legislation of Ukraine, 2005).

The Charter of the Group of States against Corruption (GRECO) was adopted in 1998. This organization brings together more than 40 members, and is today the central institutional element of the pan-European system of combating corruption. According to the Charter of the Organization, the purpose of GRECO is to improve the competence of its members in the fight against corruption through the dynamic process of jointly evaluating the methods of implementation, in accordance with their commitments in this field. To achieve this, GRECO:

- oversees the observance of the Anti-Corruption Guidelines adopted by the Council of Europe Committee of Ministers on 6 November 1997;

- oversees the implementation of international legislative instruments adopted in accordance with the Programme of Action against Corruption (Legislation of Ukraine, 1998).

The next one is Resolution (97)24 of the Committee of Ministers of the Council of Europe on the Twenty Guiding Principles for the Fight against Corruption. Its main purpose is to introduce a system of principles and stringent measures against corruption in the EU countries. A systemic analysis of the provisions of this Resolution (97)24 shows that the main task in the area of combating corruption in the EU countries is to:

- increase the level of criminal prosecution for corruption crimes;

- organize transparent cooperation between law enforcement and financial authorities;

- monitor the situation, that is, to prevent, rather than counteract corruption (NKKSPK, 2014).

Sweden, for example, by interpreting EU law provisions arbitrarily, develops and implements its own anti-corruption instruments and mechanisms that are not found in EU law. The issues of combating corruption and bribery are outlined in the general Swedish legislation, in particular the Criminal Code, the Code of Justice, the Audit Act and other legislative and regulatory acts. However, a peculiarity of the Swedish model of counteraction to corruption offences is the direct involvement in the criminal prosecution of the relevant Ombudsman in the area of public relations in which the corruption crime was committed (Suprun, 2017).

The Ombudsman exercises his powers through the oversight of the courts, prosecutors and police in solving corruption offences, effectively acting as a public overseer. In Sweden, various nongovernmental organizations also take an active part in preventing corruption. In particular, 
independent monitoring of the level of corruption in certain areas of society is carried out by the Swedish Anti-Corruption Institute, which focused on a detailed explanation of the intricacies of anticorruption legislation (Deineka et al., 2014).

In Belgium, the fight against corruption is an element of a nationwide strategy. It is determined in the National Security Plan as a means of improving the effectiveness of combating money laundering and the legalization of proceeds of crime. Therefore, the main subject of anticorruption activities is the Special Anti-Corruption Service of the Central Office for Combating Corruption. Although it is part of the Federal Police, it is empowered mainly in the field of financial control, monitoring of sources of financing of economic entities, etc.

Germany also provides quite fruitful cooperation between fiscal and law enforcement agencies in the fight against corruption, where the concept of "unjust enrichment", which is widely used in tax and civil law, is enshrined at the legislative level (Huzovatyi, 2016). In our opinion, expanding the system of combating corruption crimes in the sphere of regulatory influence of tax legislation significantly increases the ability of law enforcement agencies to trace the origin and lawfulness of the use of income and financial resources of citizens. The tools of the fiscal authorities not only extend the supervisory and monitoring opportunities of the criminal investigation authorities, but also performs a preventive function, since it significantly complicates the commission of the relevant type of crime.

The experience of criminalizing liability for accepting an offer, promise or receipt of an undue benefit under the Austrian Penal Code, pursuant to $§ 265$, which provides for criminal liability for the following acts:

- an offer, promise or guarantee of compensation in the event of a person's failure to act, or act for the benefit of others;

- demanding, accepting or promising remuneration by a person who has a necessary monopoly range of powers or ability to exercise his/her legal personality.

We draw attention to an important qualifying feature - a monopoly right or the possibility of exercising one's legal personality, which clearly determines that a person commits a criminal offence only when none else can do a similar action. It is not only a range of duties or functions assigned by the state, it is a monopoly on a particular management decision, and it is decisive in our view.

In turn, the French legislator assumed that the Convention does not clearly formulate the concept of "undue enrichment", since the possession of property is not a criminal offence itself. Therefore, criminal proceedings in French jurisprudence are instituted only if there is reason to believe that the assets of the public official were obtained illegally. Analysing the provisions of the Criminal Code of France (Golovko \& Krylova, 2002), we see that the following corruption offences are criminally punished:

- offering, directly or indirectly, without legitimate reason at any time gifts, promises, presents or any benefits;

- action or omission that falls within the powers of an official of the EU Member State or which is caused by his/her duties or mandate;

- demanding, directly or indirectly, by an official of the EU Member State without legitimate reason, at any time gifts, promises, presents or any benefits (Shmyhelskiy, 2014).

UK demonstrates an interesting experience in criminalizing punishment for accepting an offer, promise or undue benefit. Officially, this kingdom ratified the Convention, but such an offence as "undue enrichment" has not been implemented in the national legislation. However, the UK has implemented the "unexplained wealth orders" (hereinafter - "the UWO") category into national law. It is interesting that systemic analysis of the provisions of Circular 003/2018 "Criminal Finances Act: unexplained wealth orders", which introduces UWO, demonstrates the inability to identify its deterministic features with the traditional "gain of undue benefit". Thus, according to the above UWO legal act, this is a set of measures that check the nature, sources and origin of a person's wealth. The liability is applied to a person according to whether the law was violated in the process of their accumulation, but not for the enrichment process itself, and for each specific action that led to 
the illegal accumulation of wealth.

That is, the UWO provides for the need to ascertain the circumstances of how the property was obtained, where it was until receipt by the person, reasonability of the grounds for the illegally obtained income, etc. UWO is an investigation tool (GOV.UK, 2018).

Regarding the legal support of corruption in Ukraine, it should be noted that, unlike the EU countries, Ukraine has a separate special Law on Prevention of Corruption. This Law determines the legal and organizational principles of the corruption prevention system in Ukraine, content and procedure of application of preventive anti-corruption mechanisms, rules on elimination of consequences of corruption offences. In addition, this Law defines that a corruption offence is an act that contains attributes of corruption, committed by a person to whom this Law extends and for which criminal, disciplinary and/or civil liability is established (Legislation of Ukraine, 2014).

Intensification of organizational and legal support for combating corruption in Ukraine began with the adoption of the Law of Ukraine "On Amendments to Certain Legislative Acts of Ukraine on Alignment of National Legislation with the Standards of the Criminal Law Convention on Corruption" (Legislation of Ukraine, 2018). Until now, anti-corruption legislation did not meet the requirements of international legal acts. But a serious problem arose later - an extremely powerful counteraction by criminal structures and participants in corruption schemes. This led to blurred boundaries between administrative and criminal liability for corruption offences. For example, the Criminal Code of Ukraine contains Section XVII "Offences in the Field of Public Service and Professional Activities" (Legislation of Ukraine, 2020). This Section lists a number of corruption offences, but does not explicitly distinguish corruption as a purely criminal offence. Similarly, the Code of Administrative Offences contains a large number of corruption offences. This situation creates ambiguity in the consistent struggle and counteraction to corruption for Ukraine. In fact, this consistency is only nominal, but in fact there is a strong confrontation today, opposition to the attempts of the political leaders to overcome corruption on the part of the participants of corruption schemes, who, among other things, hold high political positions.

\section{Discussion}

The comparative analysis of anti-corruption issues in Ukraine and the EU states showed that there are two important differences. These differences are fundamental to understanding the differences between the governments of Ukraine and the EU in addressing corruption:

- The EU countries counteract, prevent, constantly monitor corruption, involving the public. In Ukraine, it is literally the fight against corruption. It is an element of the public administration system, as the corruption network and the system of official power have been expanding over a long period of establishing Ukrainian statehood;

- In the EU countries, corruption is a purely criminal offence. EU law excludes the possibility of weakening or mitigating the liability for corruption by decriminalizing it. In Ukraine, however, owing to the current confrontation between the corruption network and the government, the criminalization of corruption offences requires continuation and expansion.

Against this backdrop, Ukraine needs new practices to combat corruption. It is necessary to significantly expand the limits of perception of legal reality by identifying the most priority elements of the European experience, counteracted by representatives of the corruption network.

As Saprykina et al. (2011) rightly point out, one of the main directions in the field of preventing corruption in public administration should be identification of corruption risks that may arise in the activities of public servants, as well as to eliminate the conditions and causes of these risks. Since 2010, the Ministry of Justice of Ukraine has introduced, as part of the legal expertise, the examination of draft legal acts for inclusion of corruption provisions. Thus, conducting anti-corruption expertise helps to eliminate corruption factors at the stage of rulemaking (Saprykina et al., 2011).

In their turn, Olken and Rohini (2012) make a rather pragmatic conclusion that the current 
system of anti-corruption measures is aimed at introducing a reform of transparency of the authorities. Greater effect can only be achieved by disclosing information. Instead, many countries create high-profile independent anti-corruption agencies with prosecutorial powers, but their performance in a non-transparent policy and economy is ineffective (Olken \& Rohini, 2012). We cannot disagree with these scholars, because it is the public's access to the processes of counteracting corruption that is the key to effectively combating it.

For example, the experience of Slovakia shows that only the introduction of permanent mandatory monitoring and verification of information on the property rights of public servants, as well as the legalization of the Code of Ethics for Civil Servants, allowed slowing down the development of corruption relations, eliminate most of them, and dismiss officials who received undue benefits and could not explain the origin of their own wealth (Tinkov, n./d.). Such measures are applicable in all EU countries, as well as in Ukraine. But the experience of Slovakia differs from Ukraine in the fact that the Code of Ethics is an independent legislative act which sets out the requirements and, separately, the liability for violations of these requirements by public officials.

Abuse of power or undue benefit is a crime that has a complex system of proof, while it is much easier to prove violation of the requirements of the codes of ethics, therefore dismissing individuals for failure to comply with them is easier than for committed offence. The person can be dismissed only after announcing the sentence. By that time, most people continue to hold positions because of the lack of proven elements of crime.

Moos (2016) also notes another feature of corruption offences: their economic importance for public and political processes, and more specifically for the results of political decisions. Abuse of economic power can lead to the emergence of corrupt networks that consistently undermine the rule of law. In this regard, particular attention should be paid to the antimonopoly part of competition law. The relevant authorities should be able to act independently. The ethical standards introduced by the relevant codes of ethics can serve to protect against providing and receiving undue benefits in commercial activity and thus protect it (Moos, 2016). In fact, this thesis is extremely profound - the economic content of corruption relations distorts the reality and the expected effect of organizing a system of economic ties, due to the fact that these ties are not based on competition, but on corruption. And it can be eliminated by increasing the level of liability of key decision makers in the field of economy. This is not just about public officials or local self-government officials, but also about the officials of economic entities and private legal entities.

Transparency, disclosure is the most important tool for initiating monitoring and control measures against those who influence making economically significant political decisions. The mechanisms of corruption are to maximize the benefits with minimal investment, because by giving rewards stakeholders avoid competition due to the decisions adopted solely in their favour.

In this regard, Ilienok (2013) rightly draws attention to the experience of Finland, noting that the Finnish legal system is not characterized by laws using the term "fight" with a particular type of offence. The Finnish legislator has laid the principles of preventing the commission of crimes in each regulatory act, which determine a specific area of activity, not the type of offence. Belgium, in its turn, expanded the concept of corruption in relation to abuse of power, not limiting only by the criminal aspect, but also leaving room for such concepts as clarification of provisions, reminding them, transparency of behaviour, which would lead to the development of a code of conduct (Ilienok, 2013).

In addition, Suprun (2017) draws attention to another feature of the Finnish model of counteracting corruption. Finland does not implement all the provisions of all international legal acts into national law; it takes them into account, determines them only as basic starting principles for building their own national system for combating corruption. By the way, there is no term "corruption" in the Finnish legislation, as this, according to representatives of the political leaders, only limits the ability to combat this phenomenon by law enforcement agencies. This indicates that Ukraine should not follow the EU experience adopting all the Union's legislative initiatives without exception into its own legislative field. 
Romaniuk (2009) also points out that the implementation of the foreign experience must be fragmented, since it is unlikely that the Western countries at the current stage of development have such high rates of corruption as Ukraine.

Locatell et al. (2017) point out that the fight against corruption always focuses on some individual projects, in the process of state or municipal funding of major construction, infrastructure projects, and the like. Instead, corruption is a systemic phenomenon; it exists equally objectively in all sectors of the economy, if it exists in the country. And it is wrong to assume that the impact of corruption is greater if public servants or officials of private legal entities can be publicly held liable for large-scale corruption (Locatell et al., 2017). In this connection, Hamilton and Hammer (2018) rightly point out that the most harmful is medium- and small-size corruption, which is almost not visible against the background of high-profile corruption scandals. But this type of corruption creates those networks that form an alternative to the system of public administration. This conclusion is important to understand that disclosure alone will not produce the necessary positive effects, but in combination with Finland's experience, when only generic attributes of corruption are identified.

It is necessary to refer to the works of Graycar (2015), who points out the need to unify approaches to determing the nature of corruption phenomenon at the EU level in a single EU act, in order for national legislation to determine and clarify the content of corruption offences, methods of combating them on the basis of national features to the maximum possible extent. Therefore, Tabish and Jha (2012) reduce the problem of legislative consolidation of methods of combating corruption to the problem of law enforcement practice. In order to avoid such problems and inaccuracies, researchers point out that strategies of combatting and counteracting corruption need to be implemented at the national level (Tabish \& Jha, 2012). Similar strategies exist in every EU country. There is a similar strategy in Ukraine. All of them are fixed-term, and their validity is no more than three to five years. However, according to Moroff and Schmidt-Pfister (2010), the effectiveness of national strategies is heterogeneous, uneven, and differs depending on the conditions in which such a strategy is implemented. That is, it all depends on how much national governments are willing to implement them. Based on the experience of the Benelux countries, France, Germany and Poland, researchers state that the implementation of national anti-corruption strategies will be maximized when anti-corruption measures gain the nature of consistent counteraction by public authorities, local self-governments and the public, and only when corruption is criminally punishable (Moroff \& Schmidt-Pfister, 2010). Such a synthesis forces us to draw attention to the experience of Sweden considered above, in particular, to combine the efforts of civil society institutions and political forces in the fight against corruption. Sampson (2010) points out that the fight against corruption must be transformed into an independent "industry", which should become a separate special sphere of sociopolitical relations, a kind of instrument of civic control.

The Swedish model of counteracting corruption allows for this: the existence of the Ombudsman, as well as the rather severe criminal liability for corruption with a wide involvement of the public in the processes of revealing and prosecuting persons guilty of corruption offences. All the above in complex produces one of the best results in the world in combating corruption.

In his studies of the nature of corruption phenomena, Kenny (2009) concludes that the main focus of legal support for anti-corruption measures should be directed to specific sectors of the economy, namely, those in which the state places the largest number of public orders. This is what the researcher associates with corruption - non-competitive access to public finances. We agree with this point of view and believe that, indeed, the main focus of the legislative support for the fight against corruption should be directed at preventing access to the redistribution of state and municipal goods. That is, in those areas where there is a possibility, through the unlawful monopoly influence of public servants, to have unlimited access to almost unlimited financial resources and material goods.

We justify the importance of this formulation through several theses:

- monopoly means the uniqueness, inability of another person to act, to make a decision or to adopt a specific administrative act; 
- monopoly means the trust of the state to a high level of social consciousness, individual consciousness, legal culture and personal responsibility of individuals (and this is what depersonalization is important for) who occupy certain positions or have certain functions;

- monopoly means a perception by the state of the only possible scenario in the event of holding a certain position by a person - the exercise of his/her functions, powers and/or performance of duties solely on legal grounds.

All this shows that the state builds its mechanism in such a way that it acts in an entirely objective, impartial, humane and legal manner. And there is an inevitable criminal responsibility in case of its dysfunction, imbalance or violation of law, since the system clearly identifies the crime, the place of its commission and the person who committed it. The uniqueness and peculiarity of the actions and decision-making eliminates the error in identifying the subject of an offence, since it was his/her state that gave the respective monopoly.

Against this background, it is important to emphasize once again the effectiveness of a systemic approach to counteracting corruption. By the way, Kuris (2015), de Sousa (2010) and Feldman (2020) make this conclusion in their research. The first scholar notes that the direct functions of combating corruption should not only belong to the law enforcement system with the power to exert physical influence, but above all should have tools for financial, economic analysis of the origin of goods and wealth of officials and private individuals (Kuris, 2015). De Sousa (2010) also concludes that purely criminal prosecution instruments do not produce the necessary results in combating corruption. There is a need for enhanced cooperation between fiscal, financial, banking entities, analytical centers and law enforcement agencies. Actually, this model is used at its best in Germany.

According to Feldman (2020), this is the greatest value of the system of combating corruption, if we are talking about a set of public authorities, public organizations, international institutions that are aimed at combating corruption. We agree with the conclusion of most experts that only a systemic approach in combination with criminal prosecution, analytical support for monitoring, supervision and control over financial and economic relations of persons with access to monopoly management decisions will have the highest level of effectiveness.

Shim and Eom (2008) develop this thesis by talking about the system of E-Government and counteracting corruption through e-government. The researchers point out that access to online information on public finances, public procurement, civil servants' salaries will significantly reduce the very potential for corruption manifestations. But such a situation borders on the restriction of the rights to privacy, the protection of personal data, and this should be taken into account when formulating a state policy in the field of combating corruption. But we fully agree that the transparency of information, its mandatory disclosure and publicity - all lay the necessary foundations for the formation of a new quality of consciousness of public servants, both individual and public.

Graycar and Prenzler (2013) say that in order to understand the origins of corruption, they must be revealed, identified and prevented. EU anti-corruption legislation is developed in this way. Criminal codes are only the last link in the system of combating corruption. In the EU countries, corruption is seen not as an impossible phenomenon for public administration, but as an expected phenomenon in the field of public and political processes (Graycar \& Prenzler, 2013). But if it is expected, it must be either overcome or directed in the right direction.

In this context, Recantini (2011) leans towards the concept of an anti-corruption society, that is, a society that will perceive corruption as an opportunity, but will reject it because of the high level of its own moral, ethical and value orientations and qualities. Treisman (2007) also believes that over time, the legal culture of society will be so high that the public good will have a higher value than the individual economic welfare in the sense of society. That is, the society itself will reject the need to realize corruption opportunities because of a high level of legal consciousness. Seldadyo and de Haan (2011) are not so optimistic in their findings. They argue that corruption as a phenomenon is linked to particular individuals, and therefore it will last as long as the cadence of officials involved in corruption schemes will continue. Therefore, it is through criminal prosecution that researchers 
believe it is possible to achieve the greatest effect in counteracting it. We partially agree with the researchers, but still believe that corruption as a phenomenon is more systemic, and is mainly related to the transformational changes of the state mechanism, the restructuring of public institutions and the reform of the entire system of public administration.

Corruption is a consequence of the breakdown of the system, not by the state but by economic agents. Business entities that find it difficult to adjust to competition are those bifurcation points that give rise to corrupt practices. In particular, Legvold (2009) notes this, referring to the experience of combating corruption in the countries of Eastern Europe that joined the EU after the fall of the totalitarian regime.

But Forgues-Puccio (2013) warns that anti-corruption policies, which can generally be recommended to developed countries, may not be suitable for developing countries. But unambiguously, the role of anti-corruption organizations, such as Transparency International, UNCAC, the World Bank, etc. remains leading. On the other hand, Kaufmann and Pedro (2011) have come to understanding of the need to legalize, at the legislative level, much of the corruption payments that may be included in the concept of payment for administrative services. In this way, the scope of administrative services will be extended and the revenues to the state budget will increase. We insist that this approach is right, and should not be seen as an attempt to decriminalize corruption offences. On the contrary, this means of combating corruption, combined with more severe criminal punishment, is, in our opinion, the most successful combination of tools of combating corruption for Ukraine on the current way of its development.

\section{Conclusion}

Therefore, most criminal laws of foreign countries are developed on the basis of the Convention, which promotes the unification of approaches to criminalization of corruption activity. On the one hand, it allows developing certain common approaches and understandings of methods and mechanisms of combating, on the other - it opens new opportunities for differentiation of crime elements. At the same time, some criminal laws of European countries are evolving without taking into account the provisions of the Convention (Germany, Sweden), while creating their own system of qualifying attributes of corruption offences. This demonstrates the possibility of developing criminal law in Ukraine, assimilating the experience of Sweden, where the focus is not on the diversification and detailing of corruption offences, but on the tools and mechanisms of criminal prosecution of corruption, in particular through the establishment of an appropriate Ombudsman institution and broad involvement of the public in the fight against corruption.

The criminal law of some countries distinguishes between such elements of crime as bribery and undue benefit, which allows interpreting differently the activities of the persons in whose favour the officials make their decisions while exercising their powers. This opens up the opportunity of the introduction of the institute of a fully legal lobby for business interests, but it does not decriminalize real criminal acts that have a negative social effect.

In general, we can point out that the most effective approach of the organizational and legal support for combating corruption is one that covers criminal prosecution, transparency of information about public officials and private entities, as well as interaction of law enforcement agencies with fiscal authorities for the purpose of revealing sources, flows of illegal support of persons. All this requires the active involvement of civil society institutions, since only the public is able to provide the necessary level of transparency in the implementation of anti-corruption practices.

\section{References}

de Sousa, L. (2010). Anti-corruption agencies: Between empowerment and irrelevance. Crime, Law and Social Change, 53, 5-22. https://doi.org/10.1007/s10611-009-9211-3 
Deineka, V. F., Karmalita, M. V., Rozum, O. M., Shavlo, I. A., \& Shkurenko, N. G. (2014). Theoretical and legal principles of anti-corruption: scientific and analytical report. Irpin: Financial law NDI.

Feldman, D. (2020). The Efficacy of Anti-Corruption Institutions in Italy. Public Integrity. https://doi.org/10.1080/10999922.2020.1739362

Forgues-Puccio, G. F. (2013). Existing practices on anti-corruption: economic and private sector, professional evidence and applied knowledge services. Oxford: Oxford Policy Management.

Golovko, L. V. \& Krylova, N. E. (Eds.), (2002). The France Criminal Codex (N.E. Krylova Trans.). St. Petersburg: Legal Center Press.

GOV.UK. (2018). Circular 003/2018: Criminal Finances Act: unexplained wealth orders. [Online] Available: https://www.gov.uk/government/publications/circular-0032018-criminal-finances-act-unexplained-wealthorders/circular-o032018-unexplained-wealth-orders (June 7, 2020)

Graycar, A. (2015). Corruption: Classification and analysis. Policy and Society, 34(2), 87-96. https://doi.org/10.1016/j.polsoc.2015.04.001

Graycar, A., \& Prenzler, T. (2013). Understanding and preventing corruption. London: Palgrave Macmillan.

Hamilton, A., \& Hammer, C. (2018). Can we measure the power of the grabbing hand? A comparative analysis of different indicators of corruption. Policy Research working paper No. WPS 8299. Washington, D.C.: World Bank Group.

Huzovatyi, O. I. (2016). Criminal liability for illegal enrichment (comparative study) [PhD dissertation]. Dnipropetrovsk State University of Internal Affairs, Dnipro, Ukraine.

Ilienok, T. V. (2013). Combating corruption: international experience. Juridical science, 2, 71-78.

Kaufmann, D., \& Pedro, V. (2011). Legal corruption. Economics and Politics, 23(2), 195-219. https://doi.org/10.1111/j.1468-0343.2010.00377.x

Kenny, C. (2009). Transport construction, corruption and developing countries. Transport Reviews, 29 (1), $21-41$. https://doi.org/10.108o/01441640802075760

Kuris, G. (2015). Watchdogs or guard dogs: Do anti-corruption agencies need strong teeth? Policy and Society, 34(2), 125-135. https://doi.org/10.1016/j.polsoc.2015.04.003

Legislation of Ukraine. (1998). Statute of the Group of States against Corruption (GRECO). [Online] Available: https://zakon.rada.gov.ua/laws/show/994_144 (June 8, 2020)

Legislation of Ukraine. (2005). The Civil Convention on the Fight against Corruption for the sake of Europe. [Online] Available: https://zakon.rada.gov.ua/laws/show/994_102 (June 8, 2020)

Legislation of Ukraine. (2006a). Anti-Corruption Criminal Convention (ETS 173). [Online] Available: https://zakon.rada.gov.ua/laws/show/994_101 (June 7, 2020)

Legislation of Ukraine. (2006b). United Nations Convention against Corruption. [Online] Available: https://zakon.rada.gov.ua/laws/show/995_c16\#o27 (June 7, 2020)

Legislation of Ukraine. (2014). Law of Ukraine No. 170o-VII: On corruption prevention. [Online] Available: https://zakon.rada.gov.ua/laws/show/1700-18 (June 5, 2020)

Legislation of Ukraine. (2018). Law of Ukraine No. 221-VII: On amendments to some legislative acts of Ukraine to bring national legislation in line with the standards of the Criminal Convention for the Suppression of Corruption. [Online] Available: https://zakon.rada.gov.ua/laws/show/221-18\#n26 (June 5, 2020)

Legislation of Ukraine. (2020). Criminal codex of Ukraine. [Online] Available: https://zakon.rada.gov.ua/laws/show/2341-14 (June 7, 2020)

Legvold, R. (2009). Corruption, global security, and world order. Washington, D.C.: Brookings Institution Press.

Locatell, G., Mariani, G., Sainati, T., \& Greco, M. (2017). Corruption in public projects and megaprojects: There is an elephant in the room! International Journal of Project Management, 35(3), 252-268.

Moos, K. (2016). Internal report on anti-corruption measures in Europe: areas of activity, experience, tools. [Online] Available: https://www.eesc.europa.eu/sites/default/files/resources/docs/reportcorruption_ukr.pdf (June 5, 2020)

Moroff, H., \& Schmidt-Pfister, D. (2010). Anti-corruption movements, mechanisms, and machines - an introduction. Global Crime, 11(2), 89-98. https://doi.org/10.1080/17440571003669118

NKKSPK. (2014). Resolution (97) of the Committee of Ministers of the Council of Europe on the twenty principles of the fight against corruption. [Online] Available: http://nkkspk.com.ua/UK/rezolyuciya-97-24-komitetaministrov-soveta-evropy-o-dvadcati-principax-borby-s-korrupciej/ (June 5, 2020)

Olken, B. A., \& Rohini, P. (2012). Corruption in developing countries. Annual Review of Economics, 4, 479-509.

Recanatini, F. (2011). Anti-corruption authorities: An effective tool to curb corruption? In S. Rose-Ackerman, \& T. Søreide (Eds.), International handbook on the economics of corruption. Cheltenham: Edward Elgar Publishing. 
Romaniuk, B. (2009). World experience in the establishment and operation of institutions to prevent and combat corruption. Fight against organized crime and corruption (theory and practice), 21, 9-16.

Sampson, S. (2010). The anti-corruption industry: from movement to institution. Global Crime, 11, $261-278$. https://doi.org/10.108o/17440571003669258

Saprykina, M., Zinchenko, A., Liapin, D., \& Danyliuk, A. (2011). Fight against corruption. The role of business in Ukraine: an analytical reference. Kyiv: "Farbovany Lys" LLC.

Seldadyo, H., \& de Haan, J. (2011). Is corruption really persistent? Pacific Economic Review, 16(2), $192-206$. https://doi.org/10.1111/j.1468-0106.2011.00542.X

Shim, D. C., \& Eom, T. H. (2008). E-government and anti-corruption: Empirical analysis of international data. International Journal of Public Administration, 31(3), 298-316. https://doi.org/10.1080/01900690701590553

Shmyhelskiy, V. V. (2014). Criminal liability for undue advantage legislation of foreign countries. The University Scientific Notes, 4, 186-191.

Suprun, T. M. (2017). Foreign experience in preventing and combating corruption. International Legal Bulletin: current issues (theory and practice), 2-3, 199-206.

Tabish, S. Z. S., \& Jha, K. (2012). The impact of anti-corruption strategies on corruption free performance in public construction projects. Construction Management and Economics, 30(1), 21-35. https://doi.org/10.108o/01446193.2011.654128

Tinkov, A. L. (n./d.). The features of counteraction to political corruption in the EU. [Online] Available: http://academy.gov.ua/ej/ej14/txts/Tinkov.pdf (June 8, 2020)

Treisman, D. (2007). What have we learned about the causes of corruption from ten years of cross-national empirical research? Annual Review of Political Science, 10(1), 211-244. https://doi.org/10.1146/annurev.polisci.10.081205.095418 